\title{
Mrs. Turner Cut in the Web of Internalized Racism: A Black Feminist Reading of Zora Neale Hurston's Their Eyes Were Watching God
}

\author{
Parmis Tasharofi ${ }^{1}$ \\ ${ }^{1}$ Faculty of Humanities, Department of English Language and Literature, Arak Branch, Azad University, Iran \\ Correspondence: Parmis Tasharofi, Faculty of Humanities, Department of English Language and Literature, \\ Arak Branch, Azad University, Iran. E-mail: Parmis6485@yahoo.com
}

Received: February 15, 2014 Accepted: April 4, 2014 Online Published: May 27, 2014

doi:10.5539/ells.v4n2p1 URL: http://dx.doi.org/10.5539/ells.v4n2p1

\begin{abstract}
This paper is written to shed light on racism in general and internalized racism in particular. The application of the study of internalized racism on Mrs. Turner in Hurston's novel illuminates a very significant fact about the Black females now and then. Under racism which is the white imperialism and superiority, the back women have been programmed to believe in White standards of beauty and this latter is called internalized racism. Hurston so skillfully characterizes Mrs.Turner who is psychologically oppressed under this system of internalized racism. Her esteem of white skin and straight hair while she is black with kinky hair oppresses her because of her being a colored woman. Thus Race and gender converge on this issue of evaluating beauty and this purports to the belief of Black feminists that women are oppressed not only because they are women but also because they are black women.
\end{abstract}

Keywords: racism, institutionalized racism, internalized racism, black feminism, hair type, skin color

\section{Introduction}

According to Hooks (1981), specifically in the case of black and white people, the term racism is the discrimination or prejudice against black people by white people. Louis Gates Jr. claims that the word "race" is a "dangerous trope ... of ... difference between cultures, linguistic groups, or ... belief systems ..." (as cited in Guerin, Labor, Morgan, \& Willingham, 2005, p. 288).

Tyson (2006) includes that the systematic practice of racial discrimination can occur only when racism has become institutionalized. As he defines, Institutionalized racism refers to the incorporation of racist policies and practices in the institutions by which a society operates such as education, federal, state, local governments, the law both in terms of what is written on the books and how it is implemented by the courts and police officials, health care and etc.

According to Tyson, institutionalized racism leads to internalized racism. He contends that many African-Americans suffered from internalized racism and despite the success of black-pride advocates, many people of color continue to suffer from it today. Internalized racism, argues Tyson (2006), results from the psychological programming by which a racist society indoctrinates people of color to believe in white superiority. African-American women, argues Collins (2002), experience the pain of never being able to live up to prevailing standards of beauty used by White men, White women, Black men, and, most painfully, one another. One source claims that internalized racism is the racism of dominant white U.S culture which is internalized by persons of color. According to the writer, it is the conscious and subconscious incorporation and acceptance of negative stereotypes that define persons of color as inferior. According to her, colorism in the U.S. context is deeply rooted in an American form of racism grounded in Black/White oppositional differences. Featherstone recognizes the fact of Blackness, by pointing out, "Color is the ultimate test of 'American-ness', and black is the most un-American color of all" (as cited in Collins, 2002, p. 90). Cunningham (2010) claims that this form of racism supports the notion that White is right, superior and standard and that all of this can lead to a dangerous and self-destructive love affair with whiteness. He contends that internalized racism is self-hatred and that the pain of self-hatred is the primary source of many maladies among African-Americans such as homicide, incarceration, stress, high blood pressure, heart disease, diabetes, depression, grief, and etc.

As Bressler (2007) states, one of the most significant developments in literary studies in the second half of the 
twentieth century, feminist criticism advocates equal rights for all women in all areas of life. According to him, the adherents of feminist criticism are women and some men who are struggling to discover who they are, how they arrived at their present situation, and where they are going. Feminist critics argue that literature plays a central role in the development of social attitudes toward women and of women's attitudes toward themselves (Booker, 2007). But when we speak of black feminism as the third wave of the feminist movement, we are notified of a woman's oppressions not only because of her being a woman but also because of her being a black woman and then we seek to read about her freedom of that racist-sexist tyrannical situation. What differentiates black feminists from white feminists is the matter of racism, for sexism is the issue against which both of them struggle. Hooks and other black feminists insist that the fight against "racism is the fundamental conflict that all feminists who desire an end to sexism must fight" (as cited in Castle, 2007, p. 99). Hooks in her landmark work, Feminist Theory: From margin to Center argues that racism is fundamentally a feminist issue because it is so interconnected with sexist oppression (as cited in Castle, 2007). What all of these black feminists share is the desire to overcome a two-fold domination because women are oppressed not only because of their gender but also because of their race (Castle, 2007). As Wolfenstein admits, two aspects of selfhood-race and gender-are existentially fused and politically disjoined. Existentially she is a colored woman, not colored and a woman and of course not colored or a woman. Race, gender, and class interpenetrate and are inter-wined. As Wolfensteins (2008) claims, we are always inside relations of race, gender, and class. According to him, the complexities of sexual identity cannot be reduced to a normative heterosexuality.

Mrs. Turner is vividly illustrated by Hurston's elegant craft as a victim of internalized racism. The life incidents and the notions of this character in the novel shed light on her being captured by this giant system of evaluating one's beauty. She only accepts the white version of both the skin color and hair and defies her own skin and hair type. She is strongly victimized under internalized racism and since her race and gender intersect in bringing about this victimization, her oppression purports to the Black feminist reading of the novel.

\section{Discussion}

According to Ash, Hurston offers discussions of the black female's-Mrs. Turner's-encounter with the white-female standard of beauty. She discusses it best through elaboration on Mrs. Turner's notions and reactions. Through Mrs. Turner, she (1995, p. 580) shows to her readers what bad effect can be imposed upon black communities by white-controlled societies. Ash argues that Hurston gives her central character, Janie, "all of the attributes of the white-female standard of beauty". According to Neal and Wilson, Janie's countenance is like the black version of the white beauty which includes light skin and long hair (as cited in Ash, 1995). Ash (1995, p. 584) argues, "along with skin tone, Hurston uses hair not only as a primary illustration of Mrs. Turner's unqualified support of the white-female image of beauty, but also to show Mrs. Turner's attempt to get Janie to join her in that support".

According to Collins, the division of African-Americans into two categories, the "Brights" and the "Lesser Blacks," affects dark-skinned and light-skinned women differently. She (2002, p. 91) argues that darker women are judged being inferior and receive the treatment "too-big Negro girls with nappy hair" since Whites show preference for lighter-skinned Blacks. Showing Mrs. Turner being influenced by such categorization, Hurston describes Mrs.Turner: Her "shape and features were entirely approved by Mrs. Turner. Her nose was slightly pointed and she was proud. Her lips were an ever delight to her eyes. Even her buttocks in bas-relief were a source of pride. To her way of thinking, all these things set her aside from Negroes" (Hurston, 2004, p. 94). She prides herself on looking white: "Ah ain't got no flat nose and liver lips. Ah'm uh featured woman. Ah got white folks' features in my face. Still and all Ah got to be lumped in wid de rest. It ain't fair. Even if dey don't take us in wid de whites, dey oughta make us uh class tuh ourselves" (Hurston, 2004, p. 95).

According to Tyson and other critics (2006), it is generally argued that given the multiple forms of racism with which African-Americans have had to contend, many African-Americans experience what W.E.B Dubois described in the Souls of Black Folk (1903) as double consciousness or double vision, the awareness of belonging to two conflicting cultures: the African culture which grew from African roots and was transformed on American soil, and the European culture imposed by white America. As Wolfenstein (2008), contends, here we observe a desire to draw a color-line within a color-line and an accompanying double-consciousness. This experience of misrecognition is emblematic of the double-consciousness that results from seeing one's identity reflected in the veil of white prejudice. Mrs. Turner, argues Wolfenstein, even more than Joe Starks, identifies with the oppressor and so is divided within herself. He argues that the claim to veritable whiteness is shadowed by unbearable hatred of her own blackness. Because this hatred is unbearable, it is projected outward.

As we see class hierarchies in different societies such as the poor and the rich, Mrs. Turner aims to create a 
different sort of class hierarchy based on beauty. In her society, the light skinned with straight hair comes on top and the black skinned with kinky hair stands at the bottom. This fact is very evident when Mrs. Turner says: "Ah can't stand black niggers. Ah don't blame de white folks from hatin em cause Ah can't stand em mahself. 'Nother thing, Ah hates tuh see folks lak me and you mixed up wid em. Us oughta class off." Janie shows disagreement towards classing off: “Us can't do it. We'se uh mingled people and all of us got black kinfolks as well as yaller kinfolks" (Hurston, 2004, p. 94). According to Ash (1995, p. 590), Janie's beauty is so much similar to the white beauty and it is not important to her as much as it matters to Mrs. Turner. She takes a great interest in her long hair, states Ash, "not because it represents a welcome connection to white-female beauty but because it is hers". As Ash claims, when she says, "We'se uh mingled people," it illustrates her belief that African-Americans have no need to consider having light skin and straight hair superior to having dark skin and kinky hair. But Mrs. Turner doesn't pay attention to Janie as a woman but as a light-skinned woman: "She didn't cling to Janie Woods the woman. She paid homage to Janie's Caucasian characteristics as such. And when she was with Janie she had a feeling of transmutation, as if she herself had become whiter and with straighter hair ..." (Hurston, 2004, p. 96).

Ash declares that the black women today wear contact lenses and undergo different beauty surgeries in order to be as beautiful as the white beauty but according to her the easiest way to approximate such beauty is through the alteration of one's hair style. Indeed, straightening one's black hair is the best alteration to best fit into this beauty (1995). Sonia Sanchez reports, "Sisters tell me ... that when they go out for jobs they straighten their hair because if they go in with their hair natural or braided, they probably won't get the job" (as cited in Collins, 2002, p. 91). Ash (1995) recognizes the fact that women with certain styles, demeanors, and manners look more attractive to men. What appeals best to the taste of men is of consideration when a female hair style is chosen. Besides Janie's light skin, her long hair is the other factor that draws Mrs. Turner to her.

She believes that dark-skinned blacks are the source of race problem in America and that "if it wuzn't for so many black folks it wouldn't be no race problem" (Hurston, 2004, p. 95). As Ash (1995, p. 579) contends, "African-Americans with their traditionally African features have always had an uneasy coexistence with the European white ideal of beauty". U.S. Black women have been harmed by the colorism which is a by-product of U.S. racism (Collins, 2002). Neal and Wilson state that to a high degree the black woman's "obsession about skin color and features" is related to her wish to attain a "high desirability stemming from her physical similarity to the white standard of beauty" (as cited in Ash, 1995, p. 579). Janie's response reflects a knowledge of a class problem: "Ah don't figger dey ever goin tuh wants us for compa'ny. We'se too poor." However Mrs. Turner responds that the problem is color, not class. To Janie, race does not play a part in the oppression of the Africana people. Mrs. Turner comments, “Tain't de poorness, it's de color and de features" (Hurston, 2004, p. 95).

Mrs. Turner can not believe that Janie with her "coffee-and-cream complexion and her luxurious hair" is married to "a man as dark as Tea Cake." She tells her: "You got mo' nerve than me. Ah jus' couldn't see mahself married to no black man" (Hurston, 2004, p. 94). According to Lipsky, people trapped in Internalized racism tend to have controlling attitude upon those whom they have some degree of power" (2000). As it is clear, Mrs. Turner as the victim of internalized racism herself, uses her power and control over Janie. And this draws Janie's reply which shows her unconditional love of Tea Cake: "Mah husband didn't had nothin' but hisself. He's easy tuh love if you mess round 'im. Ah loves 'im" (Hurston, 2004, p. 94). We see that her love of him is not color-bound. She does not mistake love for things such as race and color."

It is as bright as the day that Mrs. Turner doesn't take a liking to Tea Cake because firstly he is a negro which is much to her dissatisfaction: Tea Cake told her, “Aw don't make God look so foolish-findin' fault wid everything He made" (Hurston, 2004, p. 97) and secondly because Tea Cake makes mockery of her and claims that "she had been shaped up by a cow kicking her from behind. She was an ironing board with things throwed at it. Then that same cow took and stepped in her mouth when she was a baby and left it wide and flat with her chin and nose almost meeting" (Hurston, 2004, p. 94). Lipsky (2000) states that internalized racism "has been a major ingredient in the distressful and unworkable relationships which we so often have with each other". Mrs Turner being strongly under the influence of a form of white-defined beauty internalization came to have an unworkable relationship with Teacake.

This is why she wants Janie meet her brother and leave Tea Cake: "She felt that she could remedy that. That was what her brother was born for" (Hurston, 2004, p. 94). "He's real smart. Got dead straight hair" (Hurston, 2004, p. 95) shows her false understanding of intelligence. In fact, she is so much oppressed mentally that her definition of intelligence is far from the genuine belief. When Mrs. Turner brings over her brother to be introduced to Janie, Tea Cake slaps Janie. 
People agree that Mrs. Turner is prejudiced and should be made to leave the area: "Sop, Ah don't think it's half de money as it is de looks. She's color-struck. She ain't got de kind of uh mind you meet every day" and Sop confirms what his friend tells him: "She figgers we's jus' uh bunch uh dumb niggers so she think she'll grow horns. But dat's uh lie. She'll die butt-headed" (Hurston, 2004, p. 99). The men buy alcohol and get drunk, and go to Mrs. Turner's restaurant. A fight breaks out between two of the men in the restaurant, which leads to a bigger fight among people in there. After the fight, Mrs. Turner decides that she and her family should leave town because she considers the people on the muck to be uncivilized. Bivens claims that racism and internalized racism manipulates self-love and the love for each other (2013). As the final touch on Mrs. Turner's life indicates, internalized racism attacks the individual life and the collective lives of people of color (2013). Mrs Tuner brought chaos and disorder to the black townspeople. The townspeople could no longer bear such person among themselves. As Lipsky states, Internalized racism has influence upon "ourselves through all manner of self-invalidation, self doubt, isolation, fear, feelings of powerlessness and despair". The atmosphere was so out of control that Mrs. Turner remained isolated.

At the final pages of chapter IVI, we see Hurston describing Mrs. Turner in such beautiful way. Her illustration of a color-struck woman is unforgettable:

Mrs. Turner, like all other believers had built an altar to the unattainable-Caucasian characteristics for all. Her god would smite her, would hurl her from pinnacles and lose her in deserts, but she would not forsake his altars. Behind her crude words was a belief that somehow she and others through worship could attain her paradise-a heaven of straight-haired, thin-lipped, high-nose boned white seraphs. The physical impossibilities in no way injured faith. That was the mystery and mysteries are the chores of gods. Beyond her faith was a fanaticism to defend the altars of her god. It was distressing to emerge from her inner temple and find these black desecrators howling with laughter before the door. Oh, for an army, terrible with banners and swords. (Hurston, 2004, p. 96)

\section{Conclusion}

Like advertising industry, the White beauty in the U.S context with its powerful advertising has manipulated the minds of so many black women in a way that they are oppressed psychologically. Being influenced under this giant superstructure, a woman can no longer be happy with herself. There is something or there are some things wrong in her appearance. Race and gender interpenetrate on this issue of evaluating beauty and this is called an intersecting racist-sexist objectification. Being brainwashed under this belief that white skin and straight hair privilege white women in a system and elevates their whiteness over blackness, black women are oppressed in a way that their psyche is their ruin.

Mrs. Turner stands for all those black women in history who are oppressed by the white idea of beauty. She as a victim of internalized racism has an African-American consciousness based on shame because of its blackness rather than one based on being proud of everything black, especially skin color.

Janie does not follow Mrs. Turner's path. Janie harbors a great interest in her being a black woman unlike Mrs. Turner and never gives into her ideas. Unlike Mrs. Turner, she considers her blackness as a sort of pride and not as a shame to herself.

Being satisfied with one's own appearance and beauty, there will be no class distinctions and hierarchies in a society. Mrs. Turner's belief in white idea of beauty made her class off and this lead to her leaving of the society. Since grass was no longer greener on this side of the fence, she had to leave and there was indeed no place for such a person who couldn't rid herself of this terrible obstacle.

Hurston tries in her novel to teach a lesson as she describes Mrs. Turner: "It was so evident that Mrs. Turner took black folk as a personal affront to herself." A woman should be delighted in her beauty and should accept her blackness with utmost delectation. Indeed, Janie advocates what Neal and Wilson claim:

The Black woman will begin to realize that the white standard of attractiveness is not suitable for her own life. Beauty is not skin deep or feature wide but encompasses a Black woman's feeling about herself, her carriage, her style, and her heritage. True Black beauty is a synthesis between physical and personality attributes. (as cited in Ash, 1995, p. 590)

According to Collins, within binary thinking, blue-eyed, blond, thin White women could not be considered beautiful without the Other-Black woman with African features of dark skin, broad noses, full lips, and kinky hair. He (2002) argues that within this binary, White and Black women represent two opposing poles, with Latinas, Asian-American, and Native American women jockeying for positions in between.

According to Turner, "Through Mrs. Turner she [Hurston] ridicules Negroes who hate their race" (as cited in 
Weems, 1989, p. 200).

\section{References}

Ash, B. D. (1995). Why don’t he Like My Hair?: Constructing African-American Standards of Beauty in Toni Morrison's Song of Solomon and Zora Neale. African American Review, 29(4), 579-592. http://dx.doi.org/10.2307/3042151

Bivens, D. (2013, November 21). Internalized Racism. Conspire. Retrieved from http://conspiremag.com/internalized-racism/

Booker, M. K. (1996). A practical introduction to literary theory and criticism. U.S.A: Longman publishers USA.

Bressler, C. E. (2007). Literary criticism: An introduction to theory and practice (4th ed.). U.S.A: Pearson Prentice Hall.

Collins, P. H. (2002). Black Feminist Thought: Knowledge, Consciousness, and the Politics of Empowerment (2nd ed.). Great Britains: Routledge.

Cunningham, G. (2010, January 19). Internalized racism and oppression [Discussion board comment]. Retrieved from http://www.docstoc.com/docs/22743718/Internalized-Racism-and-Oppression

Guerine, W. L., Labor, E., Morgan, L., Reesman, J. C., \& Willingham, J. R. (2005). A handbook of critical approaches to literature (5th ed.). New York: Oxford University Press.

Hooks, B. (1981). Ain't I a Woman: Black Women and Feminism. Boston. MA: South End Press.

Hurston, Z. H. (2004). Their Eyes Were Watching God. Retrieved from http://Harper Collins e-books.com

Lipsky, S. (2000). Internalized Racism. In N. G. Yuen (Ed.), The Politics of Liberation: An American Studies Primer (3rd ed., pp. 150-154). Kendall/Hunt publishing Company.

Tyson, L. (2006). Critical Theory Today: a User- Friendly Guide (2nd ed.). New York: Routledge.

Weems, C. H. (1989). The Tripartite Plight of African-American Women as Reflected in the Novels of Hurston and Walker. Journal of Black Studies, The African-American Woman: Complexities in the Midst of a Simplistic World View, 20(2), 192-207. Retrieved from http://www.jstor.org/stable/2784700

Wolfenstein, V. E. (2008). How Janie Got her Groove (Back): Re Negotiating Gender, Race, and Class in Their Eyes Were Watching God [Meeting Handout]. Retrieved from http://citation.allacademic.com/meta/p_mla_apa_research_citation/2/7/7/9/8/pages277989/p277989-1.php

\section{Copyrights}

Copyright for this article is retained by the author(s), with first publication rights granted to the journal.

This is an open-access article distributed under the terms and conditions of the Creative Commons Attribution license (http://creativecommons.org/licenses/by/3.0/). 